\title{
Development Concept Analysis of Higher Education in China
}

\author{
Jing $\mathrm{Wu}^{1, \mathrm{a}^{*}}$, Xiaorong Guo ${ }^{2, \mathrm{~b}}$ and Yanxiang Song ${ }^{3, \mathrm{c}}$ \\ Xijing University, Xi'an, China \\ a925884122@qq.com, b365317084@qq.com, ${ }^{\text {c29 } 291100857 @ q q . c o m ~}$
}

Keywords: Higher Education; Development Concept; International Cooperation; Structural Reform

\begin{abstract}
Since reform and opening-up, our country's higher education has achieved rapid development. China's higher education has played an important role in improving the quality of the population in China and to provide the economic development in our country. In this article, the developments of Chinese higher education were introduced simply; Opening to the outside world of Chinese higher education are illustrated; The development of our country's higher education internationalization are analyzed; The practice of our country's higher education effect were studied. China's higher education to fully implement the scientific concept of development, practical and focus on improving our quality. Our country's higher education development needs to open outside the band. The development of Chinese higher education needs combining with the condition of our country in terms of personnel training. The development of Chinese higher education needs to inherit traditional culture in the national spirit.
\end{abstract}

\section{Introduction}

After a great development in recent years, our country's higher education has played an important role in enhancing admission opportunity, meet the desire of the people accept higher education, to improve the quality of the population in China, to our country economic development and social progress, and enhance the comprehensive national strength and international competitiveness.

Higher Education Scale. After the third national education work conference, the cause of higher education into a speed up the development of deepening reform of stage. Just a few short years the time scale of higher education has a great development. In 2006 the national total of common colleges and universities and 2311 adult higher school. Among them, there are 1867 regular institutions of higher education, adult higher school there are 444. There are 720 ordinary institutions of higher learning in the college. Higher vocational college there are 1147. The total scale of higher education in China has ranked the first.

Higher Education Management System Reform Basically Completed. At present our country's higher education management system has formed the central and provincial government management, is given priority to with the provincial government as a whole management pattern. From a macro point of view, higher education management system reform has achieved a major breakthrough in the. Working through and adjustment to merge a batch of integrative and comprehensive university of talent. Form the central and provincial management is given priority to with province management system. Before and after the reform of management system, the central ministries and direct management of institutions of higher learning changed from 300 to 100 . Promotes the adjustment of the layout of colleges and universities, and improve the teaching efficiency of institutions of higher learning. From microcosmic point of view, higher school internal management system reform is deepening, the logistics socialization reform, personnel distribution system, the recruitment of students and graduates employment system reform has achieved obvious results. Formed under the planned economic system of the management mode has been broken. China's higher education in the leapfrog development, have made historic achievements.

Higher Education Quality. The Central Government has repeatedly stressed that, to fully implement the scientific concept of development in higher education, focusing on improving quality. In 2007 the Ministry of Education issued documents, decided to implement a quality project. While 
the Ministry of Education issued a circular on further deepening the reform of teaching to improve teaching quality of opinions. 25 higher education in China has entered a critical period during the consolidation, deepening reform, improving quality and sustainable development. Adhere to the scientific Outlook on development to guide the teaching of colleges and universities. In accordance with the quality requirements of the project and the number of observations, education education-oriented, with students as the main body. All the students, all depend on the students, the teaching as the central task. Adhere to the focus on cultivating innovative talents, make great efforts to deepen the reform of education and teaching under and adhere to the teaching points. Strengthening the practice teaching link, reform of practice teaching, improve the practice teaching system, adhere to the application of information technology as an important means to improve the quality of teaching. Promote the reform of teaching methods, strengthening the construction of high quality resources, adhere to the school for teachers, teacher-principal and establish effective incentive and restraint mechanisms. Fully arouse the enthusiasm of teachers, teachers ' initiative, so that all teachers are actively involved in the reform of the practice in the past.

Higher Education Educational Reform Steadily. Along with the advancement of educational system reform, has formed the common development pattern of public private higher school. Shortly after the founding of new China, due to the limited knowledge level and the historical condition at that time, actually cancelled private institutions of higher learning. Formed only at the single situation of institutions of higher learning by the government. After the third plenary session of the eleventh on the path of reform and opening up in China. In 1982 the establishment of the Chinese society university school marks the recovery of private higher education in our country. Private higher education in more than 20 years broke through strives for the survival of the status on the margins of society. Private higher education has made great development. By the end of 2006, to 278 private higher school development. Among them, there are 276 private ordinary higher school. There are 2 private adult higher school. In the school-based students 13.38 million people. There are 318 independent institute, in school-based students 14.67 million people. Although compared with public higher education, private higher education is relatively weak. But in public private higher school common development pattern has been formed.

Higher Education Structure Optimization and Type of Diversification. China's higher education hierarchy or layout structure, profound changes have taken place in the structure of higher education are in the process of popularization. Look from the hierarchy of specialized subject ratio gradually increased, the proportion tends to be reasonable. Since 2002, college enrollment began more than undergraduate. Structure, the scale of the basic subjects and the proportion is on the decline. Some practical and applied disciplines and closely related to economic and social scale and proportion of is on the rise. The proportion of humanities social sciences to further improve. In terms of the structure of the layout, on the one hand, set of institutions of higher learning to the west and tilt and extension of 17 cities, broke the institutions of higher learning focused primarily on the east and the pattern of large and medium-sized cities, the gap is closing between regions.

\section{Higher Education Open for the Public in China}

In our country in December 11, 2001 formally joined the world trade organization, China's higher education has realized the opening to the outside world. In the aspect of education in our country, therefore, is an open range is very wide. However, due to our country in the aspect of market access and national treatment at the same time also made some restrictions, so can avoid worries caused by open education service for large or controversy. Such as, for the commercial presence of education services, our country only allow foreign education institutions in the form of china-foreign cooperation in running schools in China to set up schools or other institutions of education. Cross-border delivery mode in our country for market access and national treatment is not in the form of a commitment. Therefore, remote education, electronic education, virtual university not free for Chinese students in education activities. 


\section{Reasons of Internationalization Development of Higher Education in Chinese}

Governments, institutions and individuals in the force's internal and external environment driven by common, transnational higher education in China in the form of Sino-foreign cooperation in running schools to practice.

From the external environment, late 80 's to the 90 's of the last century, at the lack of government funding for education, students under the shortage of, resulting in some developed countries higher education institutions education resources of the surplus. Facilitated by the tremendous economic pressure and pressure, these colleges and universities in their efforts to cut expenditure and raise revenue at the same time, to look to overseas education market. The late 90 's, began to mass higher education in China, and increasing domestic demand for higher education and the contradiction between effective supply ability of higher education, coupled with China's accession to WTO and related commitments in the field of education, it gives those efforts to seek development opportunities in China for foreign educational institutions entering the Chinese school provides a good opportunity. At the Government level, through Sino-foreign cooperation in running schools to enter higher education, the introduction of high quality educational resources, economic, educational, social and cultural aspects such as access to certain benefits.

\section{New Practice of Higher Education in China}

Higher education as a importer in our country, through the practice of the china-foreign cooperation in running schools gradually the development philosophy of china-foreign cooperation in running schools, and rise to systematic social behavior orientation, is used to guide the practice of china-foreign cooperation in running schools. Exhibition, along with the development of china-foreign cooperation in running schools in China activity development idea of its component has become increasingly clear.

Human resources. In 8 kinds of strategic resources to decide the country's comprehensive national strength, our country is the most potential of human resources, knowledge resources is the weakest. Human resources determine the ownership of knowledge resources, therefore, improve the quality and quantity of human resources are the strategic focus of the country. China's popularization of higher education is still in the initial stage, to make the transition from the most populous country to human resources power, the need for a national education system. Through the cooperation in running schools with foreign institutions of higher education, using the experience of developed countries and regions, cultivate a large number of with international vision, to face the international market, participate in international competition, high-quality export-oriented compound talents with ability to cross-cultural communication, is active in Chinese colleges and universities to meet the need of economic and social development of an effective way. "Through chinese-foreign cooperation in running schools, we can make up the current Chinese education in a short time required for the shortage of disciplines and to cultivate our foreign put much-needed talent." Through cooperation in running schools, the students can go abroad or in China under the condition of a relatively short time to go abroad, to accept foreign education, thus reducing the brain drain in the process of internationalization of education.

Economic benefits. China-foreign cooperation in running schools is broadening the education financing channel, some make up for the lack of funds for education, to reduce the pressure of government funds is one of the channels. The domestic many colleges and universities is the shortage of funds, through the chinese-foreign cooperation in running schools project relatively high fees, can bring to school tuition aspects such as economic interests directly, relieve the pressure on the government insufficient education funds input. "China-foreign cooperation in running schools became not out the effective way to study abroad, can meet some of the Chinese students at home to accept foreign education, learning the foreign advanced culture the demand of the knowledge of science and technology, the purpose of the education cost saving at the same time." 4 at the same time 
of saving the cost of students by education, china-foreign cooperation in running schools to a certain extent also to ease the loss of money.

Capacity building. Introduce high quality education resources standards should follow the principle of three "benefit", namely to boost all-round quality education and cultivate innovation ability; To improve the quality of higher education, vocational education; To cultivate modern construction in urgent need of various kinds of talents. Introduce foreign high-quality education resources is the key to digestion, absorption and utilization of innovation, finally is to improve the overall level of education in our country.

\section{Conclusion}

Participate in transnational higher education in our country, the development of the concept of chinese-foreign cooperation in running schools is to strengthen the construction of education system and the ability of colleges and universities. Since reform and opening-up, our country's higher education has achieved rapid development. China's higher education has played an important role in improving the quality of the population in China and to provide the economic development in our country. In this article, the development of Chinese higher education were introduced simply; Opening to the outside world of Chinese higher education are illustrated; The development of our country's higher education internationalization are analyzed; The practice of our country's higher education effect were studied. China's higher education to fully implement the scientific concept of development, practical and focus on improving our quality. Our country's higher education development needs to open outside the band. The development of Chinese higher education needs combining with the condition of our country in terms of personnel training. The development of Chinese higher education needs to inherit traditional culture in the national spirit.

\section{References}

[1] G.P.Feng: Transnational Education - International Comparative Study (Shanghai People's Publishing House, China ,2010)

[2] B.C.Ji:Our Country's Higher Education Scale Forecast Analysis in 2020, Vol. 1 (2011) No. 1, p. 305.

[3] G.S.Yi: University Chinese-Foreign Cooperation in Running Schools Mode and Operation Mechanism of Research (Shanghai University Publishing House, China 2007.)

[4] Verbik L, Merkley C: Intematinal Branch Campus - Models and Trends, Observatory on Borderless (Higher Education Report, China, 2006).

[5] Benoit Minogue: Higher Education Spending and Output-Complexity of Relationship, Peking University Education review, Vol. 2 (2013), 60.

[6] H.Y.Liu: U DP Proportion Higher Education and Social Policy Research, Vol. (2012), P. 27-28.

[7] L.J.Guo: Under Globalization of Transnational Higher Education -Point of View, Problems and China's Response (China Social Sciences Press, China, 2009)

[8] Henry m. levin. Education How to Adapt to Future-Background of American Education, Peking University Education Review, Vol. 2 (2013), p. 2-3.

[9] Y.L.Xie : Soul of European Universities Classification, Comparative Education Research, Vol.4 (2010), p. 45.

[10] J.B.Wang, H.T.Yang::New Field of Overseas Investment -New Trend of Transnational Higher Education (DongYue Review, China, 2012) 